Kielce University of Technology

${ }^{1}$ e-mail: mtelejko@tu.kielce.pl

2e-mail: stachera.aleksandra@wp.pl

\title{
THERMAL COMFORT IN UNIVERSITY COMPUTER LABORATORIES
}

\section{KOMFORT CIEPLNY W PRACOWNIACH KOMPUTEROWYCH UCZELNI WYŻSZE}

DOI: $10.30540 /$ sae-2018-020

\begin{abstract}
A b s tract
Thermal comfort defines the state of satisfaction of a person or a group of people with thermal conditions of the environment in which the person, or the group of people is staying. The state of satisfaction depends on the balance between the amount of heat produced by the organism in the process of metabolism and heat loss from the organism to the surrounding environment. It has an effect on the quality and efficiency at work, and indirectly also on the presence of symptoms of Sick Building Syndromes (SBS).

Due to differences in body structure, metabolism, clothing etc., it is not possible to create a satisfactory thermal environment for all the people staying in it. However, there are parameter values, which maintained at an appropriate level, allow to meet thermal expectations of even 95\% of people staying in this environment. The article presents the results of tests conducted in the university computer rooms. The studies included measurements and analysis of typical internal microclimate parameters: temperature, relative humidity and $\mathrm{CO}_{2}$ concentration. The results raised considerable reservations and therefore in order to assess fully the conditions of use, it has been decided to conduct evaluation of thermal comfort in rooms analysed. In addition, the surrounding surface radiation temperature and clothing insulation of users have been specified. On the basis of the obtained data, PPD and PMV index values were determined in accordance with the standard EN ISO 7730:2005 Ergonomics of the thermal environment-Analytical determination and interpretation of thermal comfort using calculation of the PMV and PPD indices and local thermal comfort criteria [3].
\end{abstract}

Keywords: Thermal comfort, PMV, PPD, microclimate, indoor air quality

\section{Streszcze nie}

Komfort cieplny określa stan zadowolenia osoby lub grupy osób z warunków termicznych środowiska, w którym osoba ta lub grupa osób przebywa. Ten stan zadowolenia zależny jest od równowagi pomiędzy ilościa ciepła wytwarzanego przez organizm w procesie metabolizmu a stratami ciepła z organizmu do otaczajacego go środowiska. Ma on wpływ na jakość i wydajność pracy, a pośrednio również na występowanie symptomów syndromów chorego budynku (SBS).

Na skutek różnic w budowie ciała, metabolizmie, ubiorze etc. nie ma możliwości stworzenia środowiska cieplnego odpowiadającego wszystkim przebywającym w nim osobom. Istnieja jednak wartości parametrów, które utrzymane na odpowiednim poziomie, pozwalaja na spetnienie oczekiwań termicznych nawet 95\% ludzi przebywajacych w tym środowisku. W artykule zaprezentowano wyniki badań przeprowadzonych w pomieszczeniach komputerowych uczelni wyższej. Badania obejmowały pomiary oraz analizę typowych parametrów mikroklimatu wewnętrznego: temperatury, wilgotności względnej oraz stężenia $\mathrm{CO}_{2}$. Uzyskane wyniki budziły spore zastrzeżenia, dlatego w celu petnej oceny warunków użytkowania zdecydowano się na przeprowadzenie oceny komfortu termicznego analizowanych pomieszczeń. Dodatkowo określono zatem temperature promieniowania powierzchni otaczajacych i izolacyjność odzieży użytkowników. Na podstawie otrzymanych danych wyznaczono wartości wskaźników PPD i PMV, zgodnie z norma EN ISO 7730:2005 Ergonomics of the thermal environment - Analytical determination and interpretation of thermal comfort using calculation of the PMV and PPD indices and local thermal comfort criteria [3].

Słowa kluczowe: komfort cieplny, PMV, PPD, mikroklimat, jakość powietrza wewnętrznego 


\section{INTRODUCTION}

The level of satisfaction with the surrounding thermal environment is called human thermal comfort [1]. Scientists have long tried to describe the human thermal environment with the help of physical variables that could be easily regulated. From the beginning of the twentieth century to the present, a lot of indices have been offered defining thermal comfort, among others: effective temperature, standard effective temperature, resulting temperature, subjective temperature, or operative temperature. However, due to the interest of individual authors only with selected parameters affecting thermal sensations, they have limited application possibilities [2]. The most satisfactory, and at the same time the most complex, approach to the problem was presented in the second half of the 20 th century by professor Ole Fanger. His thermal comfort equation has been successfully used up to now and has been the basis for determining PMV and PPD indices used to specify satisfaction with local thermal comfort according to EN ISO 7730:2005 [3].

Due to differences in metabolism, ability to acclimatisation and thermal insulation of clothing of individuals staying in the same room, it is not possible to obtain such microclimate parameters which would be assessed as comfortable by all people in the room. This applies in particular to thermal comfort [2]. In addition, the sense of thermal comfort or lack of it depends on environmental factors such as $[4-7,16]$ air temperature in the room, air-flow rate in the room, relative humidity of the indoor air, surface radiation temperature, asymmetry of the temperature distribution in the room. Therefore, it seems extremely important to determine the thermal comfort evaluation in such rooms as selected by the authors for analysis. They are characterised by rapid and relatively large changes in the parameters listed above [8]. These changes result from the characteristic equipment of computer laboratories and the specificity of their users' behaviour (regular airing of rooms during breaks between classes).

In addition to the computational determination of PMV and PPD indices, it is still possible to assess the subjective comfort using survey tests filled by people staying in the room. For this evaluation, seven point scales of thermal comfort are used [2].

\section{WPROWADZENIE}

Komfortem cieplnym człowieka nazywa się poziom zadowolenia $\mathrm{z}$ otaczającego go środowiska cieplnego [1]. Naukowcy od dawna starają się opisać środowisko cieplne człowieka przy pomocy zmiennych fizycznych, które można byłoby w prosty sposób regulować. Od początku XX wieku do chwili obecnej zaproponowanych zostało wiele wskaźników określających komfort cieplny, m.in: temperatura efektywna, standardowa temperatura efektywna, temperatura wynikowa, temperatura subiektywna czy też temperatura operatywna. Jednak ze względu na zainteresowanie poszczególnych twórców jedynie wybranymi parametrami wpływającymi na odczucia cieplne mają one ograniczone możliwości zastosowania [2]. Najbardziej zadowalające, a jednocześnie najbardziej złożone, ujęcie problemu przedstawił $\mathrm{w}$ drugiej połowie $\mathrm{XX}$ wieku profesor Ole Fanger. Jego równanie komfortu cieplnego stosowane jest z powodzeniem do dziś i stanowiło podstawę określenia wskaźników PMV i PPD służących do określenia zadowolenia z lokalnego komfortu cieplnego wg EN ISO 7730:2005 [3].

Ze względu na różnice w metabolizmie, zdolności do aklimatyzacji oraz izolacyjności cieplnej odzieży poszczególnych osób przebywających w tym samym pomieszczeniu nie można uzyskać takich parametrów mikroklimatu, które przez wszystkie osoby w pomieszczeniu oceniane byłyby jako komfortowe. Dotyczy to zwłaszcza komfortu cieplnego [2]. Ponadto poczucie komfortu termicznego bądź też jego braku zależy od takich czynników środowiskowych jak [4-7, 16]: temperatury powietrza $\mathrm{w}$ pomieszczeniu, prędkości przepływu powietrza przez pomieszczenie, wilgotności względnej powietrza wewnętrznego, temperatury promieniowania powierzchni, asymetrii rozkładu temperatury w pomieszczeniu. Zatem niezmiernie ważne wydaje się określenie oceny komfortu termicznego w takich pomieszczeniach jak wybrane przez autorów do analizy. Charakteryzują się one szybkimi i dość dużymi zmianami wymienionych powyżej parametrów [8]. Zmiany te wynikają z charakterystycznego wyposażenia pracowni komputerowych oraz specyfiki zachowań ich użytkowników (regularne wietrzenie pomieszczeń w przerwach pomiędzy zajęciami).

Poza obliczeniowym wyznaczeniem wskaźników PMV oraz PPD możliwa jest jeszcze subiektywna ocena komfortu określana przy użyciu testów ankietowych, uzupełnianych przez osoby przebywające w pomieszczeniu. Do oceny tej stosowane są siedmiostopniowe skale komfortu cieplnego [2]. 


\section{SUBJECT AND SCOPE OF RESEARCH}

The tests were conducted in two computer laboratories located on the second floor of a fivestorey university building. The rooms were located in the middle part of the floor with windows overlooking only the South. The external walls of the building were insulated with styrofoam $15 \mathrm{~cm}$ thick and the flat roof was insulated with mineral wool $20 \mathrm{~cm}$ thick. The building was equipped with a gravity ventilation system. For each of the analysed rooms, with dimensions of $8.81 \times 6.21 \times 3.32 \mathrm{~m}$, outdoor air was supplied through 2 window air inlets with a capacity of $50 \mathrm{~m}^{3} / \mathrm{h}$. It was removed by means of two exhaust ducts $14 \times 14 \mathrm{~cm}$, placed approx. 20 $\mathrm{cm}$ from the ceiling. The tests were conducted from November 2015 to October 2017 excluding summer months.

During this time, 5 series of tests were conducted. Each measurement series lasted 7 days and the interval of recording the measured values was set to 3 minutes. During the tests, the outdoor air temperature values ranged from $-8^{\circ} \mathrm{C}$ do $+10^{\circ} \mathrm{C}$ and relative humidity was from $46 \%$ to $99 \%$. Concentration of carbon dioxide in the outdoor air ranged from 380 to $630 \mathrm{ppm}$. The wind speed during the tests did not exceed the value of $5.5 \mathrm{~m} / \mathrm{s}$.

In addition to the registration of outdoor air parameters during the measurements, the registration of basic microclimate factors inside the rooms was conducted, i.e.: concentration of carbon dioxide as a quality determinant of indoor air, temperature and relative humidity of air in the rooms. In addition, the temperature of the surrounding surfaces, the air-flow rate in the room and in the ventilation ducts were measured.

\section{RESULTS OF MICROCLIMATE PARAMETER MEASUREMENTS}

The obtained results of microclimate measurements from all measurement series in both rooms had the same characteristic course of variability (Fig. 1). The lowest values of the parameters were recorded early in the morning, before starting classes. After starting to use the rooms, values of all measured quantities increased. If during the break the rooms were aired, there was a visible decrease in the value of the analysed parameters, especially the concentration of $\mathrm{CO}_{2}$ and temperature. After starting the next classes in the room, the value of the measured parameters increased again. If the rooms were not aired during the break, the drop in the measured values was small or non-

\section{PRZEDMIOT I ZAKRES BADAŃ}

Badania prowadzone były $\mathrm{w}$ dwóch pracowniach komputerowych zlokalizowanych na drugiej kondygnacji pięciokondygnacyjnego budynku uczelni wyższej. Pomieszczenia zlokalizowane były w środkowej części kondygnacji z jednostronną, południową, orientacją okien. Ściany zewnętrzne budynku ocieplone były styropianem o grubości $15 \mathrm{~cm}$, a stropodach ocieplono wełną mineralną grubości $20 \mathrm{~cm}$. Budynek wyposażono w system wentylacji grawitacyjnej. Do każdego z rozpatrywanych pomieszczeń, o wymiarach 8,81 x 6,21 x 3,32 m, powietrze zewnętrzne dostarczane było poprzez dwa okienne nawiewniki powietrza o wydajności $50 \mathrm{~m}^{3} / \mathrm{h}$. Usuwane zaś poprzez dwa kanały wywiewne o wymiarach $14 \times 14 \mathrm{~cm}$, umieszczone w odległości ok. $20 \mathrm{~cm}$ od stropu. Badania prowadzone były od listopada 2015 do października 2017 r. $\mathrm{z}$ pominięciem miesięcy letnich.

W tym czasie zrealizowano pięć serii badań. Każda seria pomiarowa trwała siedem dni, a interwał zapisu mierzonych wartości ustalono na trzy minuty. W trakcie badań wartości temperatury powietrza zewnętrznego wynosiły od $-8^{\circ} \mathrm{C}$ do $+10^{\circ} \mathrm{C}$, a wilgotność względna 46 $\div 99 \%$. Stężenie dwutlenku węgla $\mathrm{w}$ powietrzu zewnętrznym wahało się w zakresie $380 \div 630$ ppm. Prędkość wiatru w trakcie prowadzenia badań nie przekraczała wartości $5,5 \mathrm{~m} / \mathrm{s}$.

Poza rejestracją parametrów powietrza zewnętrznego w czasie pomiarów prowadzono rejestrację podstawowych czynników mikroklimatu wewnątrz pomieszczeń, tj.: stężenia dwutlenku węgla jako wyznacznika jakości powietrza wewnętrznego, temperatury oraz wilgotności względnej powietrza $\mathrm{w}$ pomieszczeniach. Dodatkowo mierzono temperaturę powierzchni otaczających, prędkość przepływu powietrza w pomieszczeniu oraz w kanałach wentylacyjnych.

\section{WYNIKI POMIARÓW PARAMETRÓW MIKROKLIMATU}

Uzyskane wyniki pomiarów mikroklimatu ze wszystkich serii pomiarowych w obydwu pomieszczeniach miały ten sam charakterystyczny przebieg zmienności (rys. 1). Wartości najniższe parametrów odnotowywano w godzinach wczesnoporannych, przed rozpoczęciem zajęć. Po rozpoczęciu użytkowania pomieszczeń wartości wszystkich mierzonych wielkości wzrastały. Jeżeli w czasie przerwy wietrzono pomieszczenia, następował widoczny spadek wartości analizowanych parametrów, zwłaszcza stężenia $\mathrm{CO}_{2}$ i temperatury. Po rozpoczęciu w sali kolejnych zajęć następował ponowny wzrost wartości mierzonych parametrów. Jeżeli w czasie przerwy nie wietrzono po- 


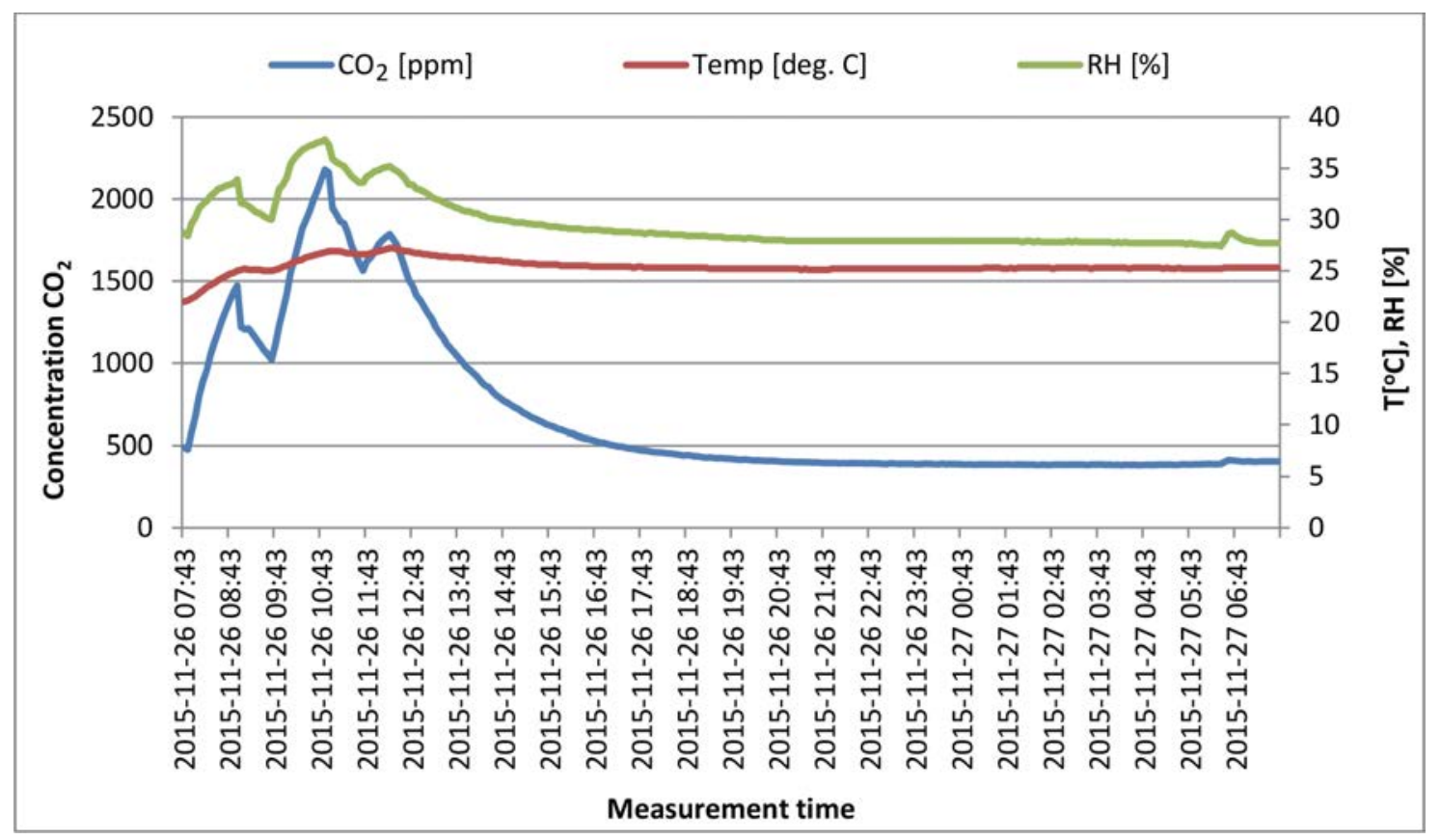

Fig. 1. The course of variability of the indoor air parameters tested for one of the tested rooms on the selected test day (start of the measurement at 7.30 am, measuring step 3 minutes)

Rys. 1. Przebieg zmienności badanych parametrów powietrza wewnętrznego dla jednej z badanych sal w wybranym dniu badań (start pomiaru o godzinie 7.30, krok pomiarowy trzy minuty)

existent. The size of the group and its composition influenced the rate of increase in the parameter value and the fact whether the recorded maximum value of carbon dioxide during the classes reached values higher than during the previous classes. For the measured values of relative humidity and indoor air temperature this dependence was not as clearly visible. However, regardless of the size of the group at the end of the classes (in the case of closed windows during classes), $\mathrm{CO}_{2}$ concentration and temperature exceeded the recommended values (Fig. 1). The maximum recorded indoor air temperature values obtained on particular days were from $25.3^{\circ} \mathrm{C}$ to as much as $28.5^{\circ} \mathrm{C}$ with average values from $23.38^{\circ} \mathrm{C}$ to $26.48^{\circ} \mathrm{C}$. Maximum recorded $\mathrm{CO}_{2}$ concentration values ranged from $1437 \mathrm{ppm}$ for a small group to $2902 \mathrm{ppm}$ for the most numerous group. The average daily values of this parameter ranged from $504 \mathrm{ppm}$ to $933 \mathrm{ppm}$. In both rooms, in all measurement series, the relative humidity $(\mathrm{RH})$ values were virtually within the recommended limits. Only for the third measurement series, in both rooms, the values of this parameter dropped below $30 \%$. mieszczeń, spadek mierzonych wartości był niewielki lub nie występował w ogóle. Liczebność grupy oraz jej skład osobowy wpływały na tempo wzrostu wartości parametrów oraz fakt, czy zanotowana w trakcie zajęć wartość maksymalna stężenia dwutlenku węgla osiągała wartości wyższe niż w czasie poprzednich zajęć. Dla zmierzonych wartości wilgotności względnej i temperatury powietrza wewnętrznego zależność ta nie była aż tak wyraźnie widoczna. Bez względu jednak na liczebności grupy pod koniec zajęć (w przypadku gdy w czasie zajęć zamknięte pozostawały okna) wartości stężenia $\mathrm{CO}_{2} \mathrm{i}$ temperatury osiągały wartości przekraczające wielkości zalecane (rys. 1). Maksymalne zanotowane wartości temperatury powietrza wewnętrznego uzyskane w poszczególnych dniach wynosiły od $25,3^{\circ} \mathrm{C}$ do nawet $28,5^{\circ} \mathrm{C}$, przy wartościach średnich od $23,38^{\circ} \mathrm{C}$ do $26,48^{\circ} \mathrm{C}$. Maksymalne zarejestrowane wartości stężenia $\mathrm{CO}_{2}$ wynosiły od 1437 ppm, w przypadku mało liczebnej grupy, do 2902 ppm w przypadku grupy najliczniejszej. Wartości średnie dobowe tego parametru wahały się od 504 ppm do 933 ppm. W obydwu pomieszczeniach we wszystkich seriach pomiarowych wartości wilgotności względnej (RH) mieściły się w zalecanych granicach. Jedynie dla trzeciej serii pomiarowej, w obydwu pomieszczeniach, wielkości tego parametru spadły poniżej $30 \%$. 
Table 1. Maximum, minimum and average values as well as standard deviations of the measured parameters [9 and own research]

Tabela 1. Wartości maksymalne, minimalne, średnie oraz odchylenia standardowe mierzonych parametrów 9 oraz badania wtasne]

\begin{tabular}{|c|c|c|c|c|c|c|c|c|c|}
\hline \multirow{2}{*}{\multicolumn{2}{|c|}{$\begin{array}{l}\text { Series } \\
\text { Room }\end{array}$}} & \multicolumn{2}{|c|}{ I } & \multicolumn{2}{|c|}{ II } & \multicolumn{2}{|c|}{ III } & \multirow{3}{*}{$\begin{array}{c}\mathbf{I V}^{*} \\
\mathrm{~A} \\
25.3\end{array}$} & \multirow{3}{*}{$\begin{array}{c}\mathbf{V}^{*} \\
\mathrm{~A} \\
25.8\end{array}$} \\
\hline & & \multirow{2}{*}{$\frac{A}{26.0}$} & \multirow{2}{*}{$\frac{B}{26.1}$} & \multirow{2}{*}{$\frac{\mathrm{A}}{27.8}$} & \multirow{2}{*}{$\frac{B}{25.6}$} & \multirow{2}{*}{$\begin{array}{c}\text { A } \\
28.5\end{array}$} & \multirow{2}{*}{$\frac{B}{27.2}$} & & \\
\hline \multirow{4}{*}{ Air temperature $\left[{ }^{\circ} \mathrm{C}\right]$} & $\max$ & & & & & & & & \\
\hline & $\min$ & 23.2 & 24.6 & 24.7 & 23.3 & 22.1 & 22 & 22.6 & 20.9 \\
\hline & average & 24.85 & 25.4 & 25.58 & 24.18 & 26.48 & 25.44 & 23.84 & 23.38 \\
\hline & standard deviation & 0.89 & 0.33 & 0.73 & 0.69 & 0.96 & 0.73 & 0.48 & 0.93 \\
\hline \multirow{4}{*}{ Relative humidity RH [\%] } & $\max$ & 48.2 & 44.7 & 42.8 & 40.4 & 35.8 & 37.8 & 53.8 & 57.0 \\
\hline & $\min$ & 36.9 & 37.4 & 33.0 & 32.6 & 26.6 & 27.4 & 37.8 & 38.2 \\
\hline & average & 41.4 & 40.7 & 34.79 & 35.49 & 29.38 & 29.6 & 43.15 & 47.43 \\
\hline & standard deviation & 2.91 & 1.45 & 1.29 & 1.21 & 2.62 & 2.57 & 4.16 & 4.57 \\
\hline \multirow{4}{*}{$\begin{array}{l}\text { Concentration of carbon } \\
\text { dioxide } \mathrm{CO}_{2}[\mathrm{ppm}]\end{array}$} & $\max$ & 1885 & 1592 & 2902 & 1437 & 2457 & 2179 & 1536 & 2857 \\
\hline & $\min$. & 432 & 456 & 445 & 460 & 412 & 382 & 485 & 415 \\
\hline & average & 770.57 & 797.33 & 667.42 & 555.52 & 880.65 & 704.99 & 504.76 & 933.28 \\
\hline & standard deviation & 404.79 & 238.21 & 318.61 & 244.93 & 549.55 & 477.49 & 351.02 & 608.79 \\
\hline
\end{tabular}

*no possibility to conduct measurements in B room

It was the result of low outdoor temperatures, and thus intensive operation of the heating system, which affected the lower relative air humidity in the room.

The measured flow rate of the air stream removed from the rooms (at the inlet to the exhaust ducts) ranged from 0.07 to $1.20 \mathrm{~m} / \mathrm{s}$. The air streams determined for the maximum values, flowing through the rooms were from $2.16 \mathrm{dm}^{3} / \mathrm{s}$ to $47.04 \mathrm{dm}^{3} / \mathrm{s}$ and did not meet the standard requirements $[10,11]$. Bearing in mind the research into the dependence between the flow of outdoor air supplied to the rooms and the efficiency of work (Fig. 2), which was made by Wargocki [12], it can be concluded that there are unfavourable working conditions for students and lecturers in both analysed computer laboratories.

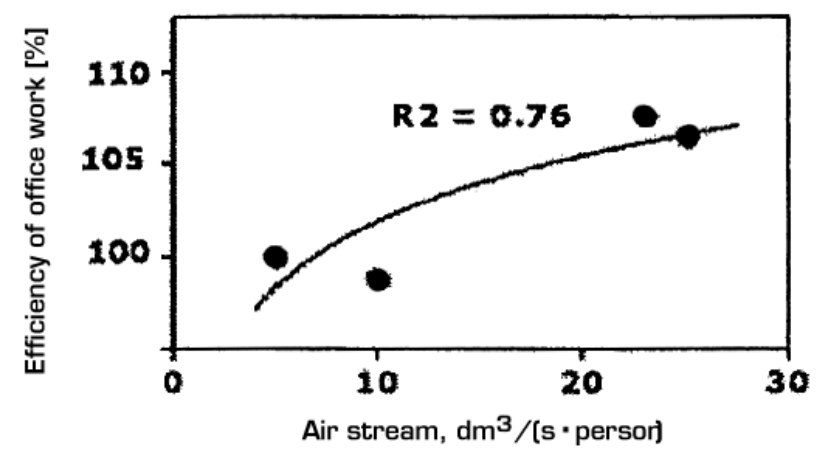

Było to wynikiem niskich temperatur zewnętrznych, a więc intensywnego działania systemu grzewczego, co wpływało na niższą wilgotność względną powietrza w pomieszczeniu.

Zmierzona prędkość przepływu strumienia powietrza usuwanego z pomieszczeń (przy wlocie do kanałów wywiewnych) wynosiła od $0,07 \mathrm{~m} / \mathrm{s}$ do $1,20 \mathrm{~m} / \mathrm{s}$. Wyznaczone dla wartości maksymalnych strumienie powietrza przepływające przez pomieszczenia wynosiły od 2,16 dm $3 / \mathrm{s}$ do $47,04 \mathrm{dm}^{3} / \mathrm{s}$ i nie spełniły wymagań normowych $[10,11]$. Mając na uwadze badania nad zależnością między strumieniem powietrza zewnętrznego dostarczanego do pomieszczeń a wydajnością pracy (rys. 2), które zostały wykonane przez Wargockiego [12], można stwierdzić, że w obydwu rozpatrywanych pracowniach komputerowych wystąpią niekorzystne warunki pracy dla studentów i prowadzących zajęcia.

Fig. 2. The dependence between the efficiency of office work and the ventilation air stream [12]

Rys. 2. Zwiąek pomiędzy wydajnościa pracy biurowej a strumieniem powietrza wentylacyjnego [12] 


\section{DETERMINATION OF PMV AND PPD INDICES AND SURVEY TEST RESULTS}

EN ISO 7730:2005 standard was the basis for the evaluation of the thermal environment in the rooms [3]. The values of environmental microclimate parameters for determining PMV and PPD indices were adopted in accordance with the measurement results described above. At the same time, measurements of the radiation temperature of the partitions and the equipment of the rooms were conducted.

On the basis of table B1 of the standard [3], the level of metabolic heat production of room users was determined. Due to the nature of the activities performed, it was assumed that all users perform office work and energy expenditure was $70 \mathrm{~W} / \mathrm{m}^{2}$. As indicated in table $\mathrm{C} 1$ of this standard, the average value of the thermal insulation of user clothing in the room was specified and was an average of 0.92 clo $\left(0.144 \mathrm{~m}^{2} \mathrm{~K} / \mathrm{W}\right)$. In addition, it was assumed that distribution of the air-flow rate was homogeneous. Based on the above findings, and in view of large spans in the average values of the basic parameters of microclimate (table 2), it was decided to specify the values of the PMV and PPD indices for each room separately. Determination of the values of these indices was conducted in accordance with the procedure described in the standard [3].

\section{OKREŚLENIE WSKAŹNIKÓW PMV I PPD ORAZ WYNIKI TESTÓW ANKIETOWYCH}

Podstawą oceny środowiska termicznego w pomieszczeniach była norma EN ISO 7730:2005 [3]. Wartości parametrów mikroklimatu środowiska do określania wskaźników PMV i PPD przyjęto zgodnie z opisanymi powyżej wynikami badań pomiarowych. W tym samym czasie realizowano pomiary wartości temperatury promieniowania przegród oraz wyposażenia pomieszczeń.

$\mathrm{Na}$ podstawie tabeli B1 normy [3] określono poziom metabolicznej produkcji ciepła użytkowników pomieszczeń. Ze względu na charakter wykonywanych czynności przyjęto, że wszyscy użytkownicy wykonuja prace biurowe i ich wydatek energetyczny wynosi $70 \mathrm{~W} / \mathrm{m}^{2}$. Zgodnie z tabelą $\mathrm{C} 1$ tej normy określono średnią wartość izolacyjności cieplnej odzieży użytkowników pomieszczeń, która wynosiła średnio 0,92 clo $\left(0,144 \mathrm{~m}^{2} \mathrm{~K} / \mathrm{W}\right)$. Ponadto przyjęto, że rozkład prędkości przepływu powietrza w pomieszczeniach jest jednorodny.

$\mathrm{Na}$ podstawie powyższych ustaleń oraz mając na uwadze duże rozpiętości średnich wartości podstawowych parametrów mikroklimatu (tabela 2), zdecydowano się na określenie wielkości PMV i PPD dla każdego pomieszczenia odrębnie. Wyznaczenie wartości tych wskaźników przeprowadzono zgodnie $\mathrm{z}$ procedurą zamieszczoną $\mathrm{w}$ normie [3].

Table 2. Values of the PMV and PPD indices for average values from obtained measurements

Tabela 2. Wartości wskaźników PMV i PPD dla wartości średnich z uzyskanych pomiarów

\begin{tabular}{|c|c|c|c|c|c|c|c|c|c|c|}
\hline \multirow{2}{*}{$\begin{array}{l}\text { Series } \\
\text { Room }\end{array}$} & \multicolumn{2}{|c|}{$I$} & \multicolumn{2}{|c|}{ II } & \multicolumn{2}{|c|}{ III } & \multicolumn{2}{|c|}{ IV } & \multicolumn{2}{|c|}{ V } \\
\hline & A & B & A & B & A & B & A & $B^{*}$ & A & $B^{*}$ \\
\hline PMV & 0.25 & 0.34 & 0.47 & 0.03 & 0.65 & 0.38 & 0.02 & - & -0.07 & - \\
\hline PPD & 6.3 & 7.4 & 9.6 & 5.0 & 13.8 & 8.1 & 5.0 & - & 5.1 & - \\
\hline
\end{tabular}

${ }^{*}$ no possibility to conduct measurements in B room

As already mentioned, in section 3 of the article, large fluctuations of the indoor air temperature during different classes were the characteristic feature of the tested rooms. Due to the relatively long exposure time of the room users to temperature variables, it was decided to estimate the values of the PPD and PMV indices also for the obtained minimum and maximum values, with the use of, registered at the time, corresponding values of the remaining parameters. In the case of maximum temperatures, the average insulation of clothing was estimated at $0.65 \mathrm{clo}$, for minimum values it remained unchanged.
Jak już wspomniano w punkcie 3 artykułu, cechą charakterystyczną badanych pomieszczeń były duże wahania temperatury powietrza wewnętrznego w czasie trwania poszczególnych zajęć. Ze względu na dość długi czas ekspozycji użytkowników pomieszczeń na zmienne temperatury zdecydowano się oszacować wartości wskaźników PMV i PPD również dla uzyskanych wartości minimalnych i maksymalnych, przyjmując do obliczeń zarejestrowane w danej chwili odpowiadające im wartości pozostałych parametrów. W przypadku temperatur maksymalnych średnią izolacyjność odzieży oszacowano na 0,65 clo, dla wartości minimalnych wartość pozostała niezmieniona. 
Table 3. Values of the PMV and PPD indices for minimum values from obtained measurements

Tabela 3. Wartości wskaźników PMV i PPD dla wartości minimalnych z uzyskanych pomiarów

\begin{tabular}{|c|c|c|c|c|c|c|c|c|c|c|}
\hline Series & \multicolumn{2}{|c|}{ I } & \multicolumn{2}{c|}{ II } & \multicolumn{2}{c|}{ III } & \multicolumn{3}{c|}{ IV } & \multicolumn{2}{c|}{ V } \\
\hline Room & A & B & A & B & A & B & A & $B^{*}$ & A & B \\
\hline PMV & 0.16 & 0.45 & 0.36 & -0.05 & -0.34 & -0.3 & -0.07 & - & -0.46 & - \\
\hline PPD & 5.5 & 9.2 & 7.7 & 5.1 & 7.4 & 6.9 & 5.1 & - & 9.4 & - \\
\hline
\end{tabular}

*no possibility to conduct measurements in B room

Table 4. Values of the PMV and PPD indices for maximum values from obtained measurements

Tabela 4. Wartości wskaźników PMV i PPD dla wartości maksymalnych z uzyskanych pomiarów

\begin{tabular}{|c|c|c|c|c|c|c|c|c|c|c|}
\hline Series & \multicolumn{2}{|c|}{ I } & \multicolumn{2}{c|}{ II } & \multicolumn{2}{c|}{ III } & \multicolumn{2}{c|}{ IV } \\
\hline Room & A & B & A & B & A & B & A & B & A & B \\
\hline PMV & 0.47 & 0.42 & 1.04 & 0.28 & 1.18 & 0.86 & 0.31 & - & 0.48 & - \\
\hline PPD & 9.6 & 8.6 & 27.8 & 6.6 & 34.2 & 20.5 & 7.0 & - & 9.8 & - \\
\hline
\end{tabular}

${ }^{*}$ no possibility to conduct measurements in B room

In order to verify the obtained results of calculations, the authors decided to conduct simple survey tests among users of computer rooms analysed. People using the laboratory had to assess the level of thermal comfort in accordance with the Bedford seven-point scale by choosing one of the possible ratings at the beginning of the classes, and one just before leaving the room, after finishing the classes. Laboratory users were 21-23 years. The size of groups ranged from 10 to 16 people, and women comprised 10 to $50 \%$ of the group. All of the people from the group that used the room during the tests participated in the surveys. In total, about 400 people participated in the tests.
W celu weryfikacji uzyskanych wyników obliczeń autorzy zdecydowali się na przeprowadzenie wśród użytkowników analizowanych sal komputerowych prostych testów ankietowych. Osoby korzystające z pracowni miały za zadanie, ocenić poziom komfortu cieplnego według siedmiostopniowej skali Bedforda, wybierając jedną z możliwych ocen na początku zajęć oraz jedną tuż przed wyjściem z sali, po zakończeniu zajęć. Użytkownikami pracowni były osoby w wieku 21-23 lat. Liczebność grup wynosiła od 10 do 16 osób, przy czym kobiety stanowiły $10 \div 50 \%$ grupy. W ankietach brały udział wszystkie osoby $\mathrm{z}$ grupy korzystającej z sali w trakcie badań. W sumie w badaniach brało udział ok. 400 osób.

Table 5. The survey test results of the users of one of the computer laboratories tested on the selected date

Tabela 5. Wyniki testów ankietowych użytkowników jednej z badanych pracowni komputerowych w wybranym dniu

\begin{tabular}{|c|c|c|c|c|c|c|c|c|}
\hline Classes & \multicolumn{2}{|c|}{1} & \multicolumn{2}{c|}{2} & \multicolumn{2}{c|}{3} \\
\hline Time of classes & beginning & end & beginning & end & beginning & end & beginning & end \\
\hline $\begin{array}{c}\text { Number of people assessing the } \\
\text { environment as comfortable }\end{array}$ & 9 & 11 & 5 & 2 & 12 & 12 & 0 \\
\hline $\begin{array}{c}\text { Number of people assessing the } \\
\text { environment as uncomfortable }\end{array}$ & 4 & 2 & 11 & 14 & 0 & 0 & 10 & 9 \\
\hline $\begin{array}{c}\text { Number of people in the room } \\
\text { Percentage of dissatisfied } \\
\text { people }\end{array}$ & 13 & 13 & 16 & 16 & 12 & 12 & 10 & 10 \\
\hline
\end{tabular}

The analysis of the results obtained allows the conclusion that the percentage of dissatisfied people is from 0 up to even $100 \%$ during different classes. It should be noted that this percentage increased along with further classes during the day. A large impact
Analiza otrzymanych wyników pozwala stwierdzić, że procent osób niezadowolonych wynosi od 0 do nawet $100 \%$ na poszczególnych zajęciach. Należy zaznaczyć, że procent ten wzrastał wraz z odbywaniem się kolejnych zajęć danego dnia. Duży 
is the fact that after finished classes, and before starting the next ones, indoor air parameters did not have initial values and they were much higher at the beginning of the classes. In this way, after four consecutive classes in the room, the authors noted situations when there were $100 \%$ negative evaluations of thermal comfort. As shown in table 5, there were also situations in which at the end of the classes, the number of people dissatisfied with thermal comfort was lower than at the beginning of the classes, or when $100 \%$ of users were satisfied with the conditions of thermal comfort throughout the classes. Such situations can be justified by the fact of airing the laboratory during classes or lack of consequence in thermal feeling evaluation. Comparison of the results obtained from the survey tests with calculated PPD index values showed that they were consistent only in few cases. The maximum determined PPD value amounted to $34.2 \%$, and as already mentioned above, the survey tests gave results of even $100 \%$ people dissatisfied with thermal comfort.

\section{DISCUSSION}

In Poland, from the point of view of ensuring conditions of thermal comfort in rooms, winter is the most difficult period. This is mainly due to ensuring properly high indoor temperature. A further complication might be equipment of the rooms, as was the case in the rooms analysed by the authors. A large number of computers that worked without even a break for about 9 hours affected the internal microclimate parameters. In conjunction with the little efficient gravity ventilation system and the lack of the possibility to adjust its work resulted in large fluctuations of the internal microclimate parameters throughout the day, and especially the values of the indoor air temperature and $\mathrm{CO}_{2}$ concentration.

The conducted accurate analyses involving determination of thermal comfort indices, did not give positive results. For specific average values of microclimate parameters, the determined PMV index values are not within the limits of the thermal comfort, i.e. $-0.5<\mathrm{PMV}<0.5$. The maximum value of the PMV index for these values amounted to 0.65 , and the percentage of people dissatisfied with the microclimate parameters (PPD) reached even $13.8 \%$. For the registered maximum values of the parameters measured, the percentage of people dissatisfied with the conditions of thermal environment, calculated according to the standard [3], wpływ ma na to fakt, iż po zakończonych zajęciach, a przed rozpoczęciem następnych, parametry powietrza wewnętrznego nie przyjmowały wartości początkowych i już na początku zajęć były o wiele wyższe. W ten sposób po czterech kolejnych zajęciach w danej sali autorzy odnotowali sytuacje, gdzie wystąpiło 100\% negatywnych ocen komfortu cieplnego. Jak wynika z tabeli 5 zdarzały się również sytuacje, w których na końcu zajęć liczba osób niezadowolonych z komfortu cieplnego była mniejsza niż na początku zająć lub gdy 100\% użytkowników była zadowolona z warunków komfortu cieplnego przez cały czas ich trwania. Sytuacje takie można uzasadnić faktem wietrzenia pracowni w czasie zajęć lub też brakiem konsekwencji oceny odczuć termicznych. Porównanie otrzymanych wyników z testów ankietowych z wyznaczonymi obliczeniowo wartościami wskaźnika PPD wykazały, że tylko w nielicznych przypadkach są one ze sobą zbieżne. Maksymalna wyznaczona wartość PPD wyniosła $34,2 \%$, a jak już wspomniano powyżej, testy ankietowe dały wyniki nawet $100 \%$ niezadowolonych z komfortu cieplnego.

\section{PODSUMOWANIE}

W Polsce najtrudniejszym okresem z punktu widzenia zapewnienia warunków komfortu cieplnego w pomieszczeniach jest zima. Wiąże się to głównie $\mathrm{z}$ zapewnieniem odpowiednio wysokiej temperatury wewnętrznej. Dodatkowym utrudnieniem może być wyposażenie pomieszczeń, jak miało to miejsce w rozpatrywanych przez autorów pomieszczeniach. Duża ilość komputerów, które pracowały bez przerwy nawet przez ok. 9 godzin, wpływała na parametry mikroklimatu wewnętrznego. W połączeniu z mało wydajnym systemem wentylacji grawitacyjnej oraz brakiem możliwości regulacji jego pracy skutkowało to dużymi wahaniami parametrów mikroklimatu wewnętrznego w ciągu doby, a zwłaszcza wartości temperatury powietrza wewnętrznego oraz stężenia $\mathrm{CO}_{2}$.

Przeprowadzone dokładne analizy, polegające na wyznaczeniu wskaźników komfortu termicznego, nie dały pozytywnych wyników. Dla określonych średnich wartości parametrów mikroklimatu wyznaczone wartości wskaźnika PMV nie mieszczą się w granicach komfortu termicznego, tj. - $0,5<\mathrm{PMV}<0,5$. Maksymalna wartość PMV dla tych wartości wynosiła 0,65 , a odsetek osób niezadowolonych z parametrów mikroklimatu (PPD) sięgnął nawet 13,8\%. Dla zarejestrowanych wartości maksymalnych mierzonych parametrów wyliczony zgodnie z normą [3] odsetek osób niezadowolonych z warunków środowiska termicznego wy- 
amounted to $34.2 \%$, and the maximum value of the PMV index was even 1.18. Only for minimum values, the received indices do not raise significant reservations. It should be noted, however, that the minimum values were temporary and registered only and solely at the beginning of the classes. In contrast, the results of survey tests conducted among the room users are surprising. In most cases, more than 50\% of respondents in the group of students that used the laboratory defined the temperature inside the rooms as uncomfortable. In the case of certain groups of students, even $100 \%$ of the respondents negatively rated thermal comfort in the room.

The test results of microclimate parameters presented in the article indicate unequivocally that the indoor air quality in the analysed rooms is poor. Taking the maximum recorded $\mathrm{CO}_{2}$ concentration values into consideration, the quality can be specified as the category IDA 4 according to the requirements of the standard [13]. The maximum content of carbon dioxide in the indoor air exceeded $2900 \mathrm{ppm}$. The already mentioned standard [13] and ASHRAE guidelines [14] in the rooms intended for permanent stay of people consider this parameter as limit value at $700 \mathrm{ppm}$ above the level of carbon dioxide content in the air outside the building. For the concentrations of $\mathrm{CO}_{2}$ obtained during measurements in the outdoor air, the limit value can therefore be considered as approximately $1100 \mathrm{ppm}$. Also, the maximum temperature values in the analysed rooms exceeded the values recommended for thermal comfort. In the vast majority the average temperature values obtained in the computer laboratories analysed, exceeded $24^{\circ} \mathrm{C}$. Only the recorded values of the relative humidity, except for one measurement series, did not raise major reservations.

In conclusion, it should be noted that computer laboratories are a very specific type of rooms and obtaining the appropriate internal microclimate parameters and a comfortable temperature in them is very difficult in the case of applying gravity ventilation. The introduction of requirements to install mechanical devices for controlling indoor air parameters in these types of rooms seems to be proper.

The obtained discrepancies between the calculated values of the PPD parameter and survey test results must be verified again in a larger group of respondents. niósł 34,2\%, a maksymalna wartość wskaźnika PMV aż 1,18. Jedynie dla wartości minimalnych otrzymane wskaźniki nie budzą większych zastrzeżeń. Należy jednak zaznaczyć, że wartości minimalne były wartościami chwilowymi rejestrowanymi tylko i wyłącznie na początku zajęć. Zaskakujące są natomiast wyniki przeprowadzonych testów ankietowych wśród użytkowników pomieszczeń. W większości przypadków ponad $50 \%$ badanych w danej grupie studentów korzystającej z pracowni określiło temperaturę wewnątrz pomieszczeń jako niekomfortową. W przypadku niektórych grup studentów nawet 100\% ankietowanych negatywnie oceniło komfort termiczny w sali.

Przedstawione w artykule wyniki badań parametrów mikroklimatu wskazują jednoznacznie, że w rozpatrywanych pomieszczeniach jakość powietrza wewnętrznego jest niska. Mając na uwadze maksymalne zanotowane wartości stężenia $\mathrm{CO}_{2}$, jakość tę można określić kategorią IDA 4 według wymagań normy [13]. Maksymalna zawartość dwutlenku węgla w powietrzu wewnętrznym osiągnęła ponad 2900 ppm. Wspomniana już norma [13] oraz wytyczne ASHRAE [14] w pomieszczeniach przeznaczonych na stały pobyt ludzi za wartość graniczną tego parametru uznają wielkość 700 ppm powyżej poziomu zawartości dwutlenku węgla w powietrzu na zewnątrz budynku. Dla uzyskanych w trakcie pomiarów wartości stężenia $\mathrm{CO}_{2} \mathrm{w}$ powietrzu zewnętrznym za wartość graniczą można zatem uznać około 1100 ppm. Również maksymalne wartości temperatury $\mathrm{w}$ badanych pomieszczeniach przekraczały wartości zalecane dla komfortu cieplnego. W zdecydowanej większości uzyskane wartości średnie temperatury $\mathrm{w}$ rozpatrywanych pracowniach komputerowych przekraczały $24^{\circ} \mathrm{C}$. Jedynie odnotowane wartości wilgotności względnej, poza jedną serią pomiarową, nie budziły większych zastrzeżeń.

Podsumowując, należy stwierdzić, że pracownie komputerowe stanowią bardzo specyficzny rodzaj pomieszczeń i osiągnięcie $\mathrm{w}$ nich właściwych parametrów mikroklimatu wewnętrznego oraz temperatury komfortowej jest bardzo trudne w przypadku zastosowania wentylacji grawitacyjnej. Słusznym wydaje się wprowadzenie wymagań, aby w tego typu pomieszczeniach instalowane były urządzenia mechaniczne pozwalające na kontrolowanie parametrów powietrza wewnętrznego.

Uzyskane rozbieżności pomiędzy obliczonymi wartościami parametru PPD a wynikami testów ankietowych muszą być jeszcze zweryfikowane na większej grupie ankietowanych. 


\section{References}

[1] McIntyre D.A., Seven point scales of warmth, ECRC/M957, Copenhurst, Chester, 1976.

[2] Śliwowski L., Mikroklimat wnętrz i komfort cieplny ludzi w pomieszczeniach [Interior microclimate and thermal comfort of people in rooms], Publishing House of the Wrocław University of Technology, Wrocław 2000.

[3] EN ISO 7730:2005: Ergonomics of the thermal environment - Analytical determination and interpretation of thermal comfort using calculation of the PMV and PPD indices and local thermal comfort criteria.

[4] Popiołek Z., Energy efficient development of the internal environment, Department of Heating, Ventilation and extraction techniques, Silesian University of Technology, Gliwice 2005 (in Polish).

[5] Wargocki P., Wyon D., Matysiak B., Irgens S., The effects of classroom air temperature and outdoor air supply rate on performance of school work by children, Proceedings of Indoor Air 2005, The 10th International Conference on Indoor Air Quality and Climate, Beijing, China 2005, pp. 368372.

[6] Nantka M.B., Natural air exchange and the tightness of the housing, Ventilation Forum 2005, Warsaw 2005 (in Polish).

[7] Popiołek Z., Proceedings of Workshop Measurement and Control Techniques for HVAC System and Indoor Climate, ENER-INDOOR, Gliwice 2005.

[8] Telejko M., Attempt to improve indoor air quality in computer laboratories, Procedia Engineering, Volume: 172, Issue: 2017, Pages: 1154-1160.

[9] Stachera A., Smorenda K., Mikroklimat w pracowniach komputerowych Politechniki Świętokrzyskiej [Microclimate in computer laboratories of the Kielce University of Technology], Engineer thesis under the supervision of dr inż. M. Telejko, Kielce University of Technology, WBiA, Kielce 2016.

[10] PN-83/B-03430 Wentylacja $w$ budynkach mieszkalnych zamieszkania zbiorowego i użyteczności publicznej. Wymagania, PKN, 1983 (Ventilation in dwellings and public utility buildings. Specification).

[11] PN-83/B-03430:Az03 Wentylacja w budynkach mieszkalnych zamieszkania zbiorowego i użyteczności publicznej. Requirements. Zmiana Az3, PKN, 2000 (Ventilation in dwelling and public utility buildings. Specification. Amendment Az3).

[12] Popiołek Z., Jakość powietrza wewnętrznego a zużycie energii (w:) Energooszczędne ksztaltowanie środowiska wewnętrznego [Indoor air quality and energy consumption (in:) Energy-efficient shaping of the internal environment], Z. Popiołka; Gliwice 2005.

[13] PN-EN 16798-3:2017-09 Charakterystyka energetyczna budynków. Wentylacja budynków. Część 3: Wentylacja budynków niemieszkalnych. Wymagania dotyczace właściwości systemów wentylacji i klimatyzacji pomieszczeń [The energy performance of buildings. Ventilation of the buildings. Part 3: Ventilation for non-residential buildings. Performance requirements for ventilation and room conditioning systems].

[14] ASHRAE Standard 62.1-2016, "Ventilation for Acceptable Indoor Air Quality".

[15] PN-EN 15251:2012 Parametry wejścioweśrodowiska wewnętrznego dotyczace projektowania ioceny charakterystyki energetycznej budynków, obejmujące jakość powietrza wewnętrznego, środowisko cieplne, oświetlenie i akustykę [Indoor environmental input parameters for design and assessment of energy performance of buildings- addressing indoor air quality, thermal environment, lighting and acoustics].

[16] Zender-Świercz E., Analysis of the impact of the parameters of outside air on the condition of indoor air. International Journal of Environmental Science and Technology August 2017, Volume 14, Issue 8, pp. 1583-1590.

\section{Acknowledgments:}

This work was supported by Kielce University of Technology, Grant No. 02.0.05.00/2.01.01.01.0028 MNSP BKTO.15.003

\section{Podziękowania:}

Praca była finansowana przez Politechnikę Świętokrzyska, grant nr 02.0.05.00/2.01.01.01.0028 MNSP BKTO.15.003 